\title{
Two EUROPEAN CONFLICTS CONVENTIONS
}

\author{
Friedrich K Juenger*
}

The states of the European Union have so far concluded two major conflict of laws conventions: The Brussels Convention on Jurisdiction and the Enforcement of Judgments in Civil and Commercial Matters, and the Rome Convention on the Law Applicable to Contractual Obligations. Professor Juenger here reflects on the creation and experience of these treaties and concludes that the Brussels/Lugano Conventions present a model for the world while the Rome Convention shows what to avoid.

\section{INTRODUCTION}

Regions that combine unity with legal diversity provide a fertile soil for the evolution of the conflict of laws. ${ }^{1}$ Such conditions existed during the late Middle Ages in Upper Italy, where an over-arching ius commune coexisted with the city states' statuta. This configuration prompted glossators and commentators, who taught Roman law - which they believed to be a timeless ratio scripta - but lived within city walls, to wrestle with choice of law problems. Undaunted by the fact that Justinian's Code failed to deal with the conflict of laws, they nevertheless found a place in the Corpus Juris, the lex cunctos populos, to which they appended their discussions of the subject. Beginning with Magister Aldricus, these medieval scholars created the field of conflict of laws, about which Bartolus ultimately wrote an important

* Edward L Barrett, Jr, Professor of Law. This article is a revised version of papers delivered on 23 February 1998 to the New Zealand Association of Comparative Law at the Faculty of Law of the Victoria University of Wellington and on 16 March 1998 at a Staff Seminar at Otago University. It reflects prior research and conclusions developed in connection with a contribution to the Festschrift für Ulrich Drobnig to be published by the Hamburg Max-Planck-Institut für ausländisches und internationales Privatrecht.

1 For a brief history of the conflict of laws see F Juenger Choice of Law and Multistate and Justice (Martinus Nijhoff Publishers, Dordrecht, Boston, London, 1993) 6-42. 
commentary, out of whole cloth. Subsequently France, a monarchy the bulk of whose laws was regional rather than national, provided a similarly felicitous setting. In the sixteenth century that country produced several distinguished conflicts writers, notably Dumoulin and d'Argentré. During the seventeenth century, the Voets and Huber made important contributions when they wrestled with the conflicts problems of The Netherlands, a major trading nation whose constituent provinces were, however, fiercely independent. Later on Friedrich Carl von Savigny forged a conflict of laws system in Germany, then a conglomerate of states with a common language and usus modernus pandectarum but widely differing statutory and customary laws.

In marked contrast to the legal diversity that prevailed on the European Continent, England - where legal fragmentation had yielded to the unifying force of the common law contributed nothing to the conflict of laws before the 1707 Treaty of Union with Scotland. Transnational legal problems engendered by England's maritime, trading and colonising activities used to go to mercantile and admiralty tribunals, which applied a law merchant of universal purport, whilst the common law courts used to stay away from it. Initially, they simply dismissed actions arising out of the realm; later on judges resorted to the fiction that what happened abroad had occurred in England, so that the common law applied. Given Scotland's civil law tradition it is understandable that Scottish rather than English jurists notably Lord Kames and Lord Mansfield - were the first contributors to the British conflict of laws. ${ }^{2}$ In fact, within the common law world, the conflict of laws was rather slow to develop, until the subject assumed importance in the American setting, where in spite of national unity the bulk of the law derived from state rather than federal sources. An American judge and scholar, Joseph Story, who drew upon the rich continental European literature, wrote a landmark treatise on the subject. Demonstrating that the comparative method is not a oneway street, that book, because of its intrinsic merit, became influential not only in the common law world but in civil law countries as well.

The Europe of our days has witnessed the emergence of a new supranational entity, the European Union. Although the EU has not attained the status of a "United States of Europe", its quasi-federal system bears a distinct resemblance to the US, combining as it does a measure of economic and political unity with legal diversity. Given the intensity of interaction between its member states, the EU was predestined to yield initiatives in the

2 Concerning the evolution of the Scottish conflict of laws see AE Anton and PR Beaumont Private International Law (2ed W Green, Edinburgh, 1990) 9-12. 
conflict of laws. What it has contributed to this field so far not only invites comparison with developments in the US, but may also be of interest to other nations that have embarked on a course of regional economic integration. To date the EU member states have concluded two major conflict of laws conventions: (1) the 1968 Brussels Convention on Jurisdiction and the Enforcement of Judgments in Civil and Commercial Matters, and (2) the 1980 Rome Convention on the Law Applicable to Contractual Obligations. Thus, the EU's member states - while not codifying the entire field of conflicts law - have, by means of international compacts, dealt with all three of the subjects encompassed by the conflict of laws: jurisdiction, judgments recognition and choice of law.

\section{JURISDICTION AND JUDGMENTS}

\section{A Full Faith and Credit in Europe}

Whereas the United States Constitution contains a Full Faith and Credit Clause ${ }^{3}$ which has played a role in American conflicts law, ${ }^{4}$ especially as regards the recognition of sister-state judgments, the European Founding Fathers failed to include a comparable provision in the European Community's constitutive document, the 1957 Treaty of Rome. Its article 220 merely lists the "simplification of formalities" of judgments recognition and enforcement among the topics for future member states negotiations. Notwithstanding the rather limited purview of this provision, the committee of experts appointed to draft a convention that would implement the Rome Treaty's mandate construed its brief much more broadly. Instead of limiting their efforts to formalities, these experts produced a remarkable instrument that, in effect, supplied the ingredient that was missing in the European Community's constitution. Their work product, the 1968 Brussels Convention on Jurisdiction and Enforcement of Judgments in Civil and Commercial Matters, established a system that is not merely comparable but superior to the practice of American courts under the Full Faith

3 US Const article 4 section 1.

4 "The full faith and credit clause ... became a nationally unifying force.

It altered the status of the several states as independent foreign sovereignties, each free to ignore rights and obligations created under the laws or established by the judicial proceedings of the others, by making each an integral part of a single nation, in which rights judicially established in any part are given nation-wide application "Magnolia Petroleum Co v Hunt (1943) 320 US 430, 439. 
and Credit Clause. A resounding success in practical application, this "revolutionary" convention effectively created a European law of civil procedure. ${ }^{6}$

\section{B Borrowing from America?}

The parallels between the Brussels Convention and US practice are sufficiently striking to permit the inference that the committee of experts borrowed from America. While there is no concrete evidence for this proposition (the committee shredded its travaux préparatoires and publications by its members do not mention American law as source of inspiration), it would be strange indeed if the European experts had entirely disdained recourse to the comparative method. Some of its members were comparativists who could draw on an extensive US case law and literature at a time when comparatively little had been published in Europe on jurisdiction and judgments recognition. They could hardly have been ignorant of the American model when they drafted the Brussels Convention given the fact that the European Community's member states were then negotiating, under the auspices of the Hague Conference on Private International Law, a judgments recognition convention. In fact, two members of the committee of experts also served in The Hague, where they were surely exposed to American thinking on these subjects. But to the extent that the Brussels Convention's drafters did copy American practice, their copy is better than the original.

\section{Jurisdiction}

\section{American law}

The American jurisdictional law is rather less than satisfactory. ${ }^{7}$ Since the Congress, though arguably empowered to do so by the Full Faith and Credit Clause, never legislated on the subject, it fell to the states to elaborate pertinent rules and principles. They enacted a panoply of so-called "long-arm statutes", which the highest state courts have usually construed in a fairly permissive manner, to subject nonresident individuals and corporations to the jurisdiction of domestic courts. The US Supreme Court has, however, long claimed the power to subject state jurisdictional assertions to constitutional scrutiny. ${ }^{8}$ (Surprisingly, the

5 Droz "Entrée en vigeur de la Convention de Bruxelles concernant la compétence judiciaire et l'exécution des décisions en matière civile et commerciale" (1973) Revue critique de d.i.p. 21, 22.

6 J Kropholler Europäisches Zivilprozessrecht (5ed Verlag Recht und Wirtschaft, Heidelberg, 1996$) 28$.

7 For critical voices see "Symposium - Fifty Years of International Shoe: The Past and Future of Personal Jurisdiction" (1995) 28 UC Davis L Rev 513.

8 See Pennoyer v Neff (1877) 95 US 714. 
Court based this prerogative not on the Full Faith and Credit Clause but on the Due Process Clause of the Fourteenth Amendment to the US Constitution, a clause that deals with human rights rather than territorial constraints on state sovereignty. ${ }^{9}$ ) In exercising its role as the ultimate arbiter of jurisdictional propriety, the Court has deduced from the Due Process (which says nothing about jurisdiction) some rather amorphous and confusing principles. It proclaimed that to be amenable to jurisdiction, a nonresident defendant must have certain "minimum contacts" with the forum state by virtue of the fact that he "purposefully availed" himself of the privilege of conducting activities within that state. ${ }^{10}$ In addition, the assertion of jurisdiction must be fair under the circumstances. ${ }^{11}$ Since these shibboleths are hardly selfexplanatory and the Court's case law is less than pellucid, counsel, courts and even law professors find it difficult to fathom the parameters of American state court jurisdiction.

Nor do the Justices seem to be entirely sure about the meaning of their own pronouncements, as the numerous dissents and concurrences in jurisdictional cases show. In several instances, they were unable to muster a majority on the question of how the fluid concepts they devised should be applied to the facts at hand. The Supreme Court's lengthy, highly footnoted and frequently impenetrable opinions not only confuse bench and bar but they are also apt to produce questionable results. For instance, it is difficult to understand why elementary fairness, which the Due Process clause is designed to guarantee, should shield a New York father from a California action for child support brought by his daughter, whom he had sent to her mother in California with a one-way ticket. ${ }^{12}$ Conversely, although the common law rule, that mere service within the forum state confers jurisdiction over a non-resident defendant, a rule the Brussels Convention blacklists, ${ }^{13}$ can hardly be squared

9 Whereas Justice White once argued that the Due Process Clause, "acting as an instrument of interstate federalism, may sometimes act to divest the State of its power to render a valid judgment", World-Wide Volkswagen Corp v Woodson, (1980) 444 US 286, 294, he recanted this position in Insurance Corp of Ireland $v$ Compagnie des Bauxites de Guinee (1982) 456 US 694, 702 n10, where he somewhat incongruously proclaimed that the "restriction on state sovereign power described in World-Wide Volkswagen Corp... must be seen as ultimately a function of the individual liberty interest preserved by the Due Process Clause".

10 See Hanson v Denckla (1957) 357 US 235; International Shoe Co v Washington (1945) 326 US 310.

11 Asahi Metal Ind Co v Superior Court (1987) 480 US 102.

12 See Kulko v Superior Court (1978) 436 US 84.

13 See text preceeding $\mathrm{n} 20$ below. 
with elementary notions of fairness, the Court has held such "tag jurisdiction" does not violate the Due Process Clause. ${ }^{14}$

\section{The Brussels Convention}

In contrast to the welter of discordant state laws and the untidy US Supreme Court jurisprudence, the jurisdictional bases set forth in the Brussels Convention are fairly straightforward and present fewer problems in practical application. Emulating American Supreme Court review, the 1971 Luxembourg Protocol provides for a reference to the Court of Justice of the European Communities of questions concerning the interpretation of the Convention by domestic courts. Thus remaining uncertainties and ambiguities can be ironed out by the Court, which so far has rendered over a hundred decisions (unlike the US Supreme Court, it does not enjoy the luxury of discretionary review) that primarily clarify jurisdictional points, but also other issues posed by the Brussels Convention.

The Convention's rules on jurisdiction are not only more clearly delineated; they are also better attuned to the protection of fundamental values. While the US Supreme Court tends to treat all litigants alike, the Convention is more discerning: for instance, it bestows jurisdictional privileges upon certain weaker parties, such as support claimants, ${ }^{15}$ policyholders ${ }^{16}$ and consumers, who are allowed to sue in their home states. ${ }^{17}$ By the same token, contrary to US precedent ${ }^{18}$ the Convention severely restricts the use of forum-selection clauses against such parties. ${ }^{19}$ It also prohibits the use of the exorbitant member state jurisdictional bases enumerated in article 3(2) of the Brussels Convention. This provision lists, inter alia, not only the notoriously chauvinistic article 14 of the French Civil Code (which allows French plaintiffs to sue anyone on any cause of action in France) and section 23 of the German Code of Civil Procedure (which grants German courts full in personam jurisdiction

14 Burnham v Superior Court (1990) 495 US 604.

15 Article 5 No 2.

16 Article 8(1) No 2.

17 Article 14(1).

18 Carnival Cruise Lines, Inc. v Shute (1991) 499 US 585.

19 See Brussels Convention articles 12 (insurance matters), 15 (consumers), 17(5) (employment contracts). 
over nonresident defendants who own assets in Germany), but also the common law rule that confers jurisdiction over defendants who have been served within the forum state. ${ }^{20}$

\section{Recognition and Enforcement of Judgments}

With respect to the recognition and enforcement of judgments as well, the Brussels Convention's rules are superior to those used in American interstate practice. To be sure, in the US most states provide for summary procedures that eliminate the inconvenience of a full-fledged action on the judgment the common law used to require. But there is no quasiautomatic enforcement upon a mere application (or, in the case or the United Kingdom and Ireland, registration) as under the Brussels Convention; ${ }^{21}$ in the US the faith and credit a sister state judgments enjoy is therefore not quite as full as in the EU. The Brussels Convention's scheme thus represents a remarkable achievement, especially if one considers that in Europe judgments have to cross national frontiers rather than mere state borders and that the EU's member states share neither a common law nor a common language.

\section{E Evaluating the Brussels Convention}

This is not to say that the Brussels Convention has no flaws. The commission of experts left open some important issues, such as whether the place of acting, the place of injury, or both, have jurisdiction in tort cases. ${ }^{22}$ For jurisdiction in contract disputes article 5 No 1 selects the "place of performance of the obligation in question", a solution that owes more to Savigny's musings ${ }^{23}$ and obsolete member state rules than sound policy. Unsurprisingly, this provision has caused difficulties in practical application and legal writers have called for its abolition. ${ }^{24}$ More serious yet is the Convention's blatant discrimination against outsiders. Article 4 allows the use of exorbitant member state jurisdictional assertions (which, according to article 3, may no longer be invoked against EU residents) against parties domiciled outside

20 See article 3(2), under "Ireland" and "United Kingdom".

21 See Brussels Convention articles 31-45.

22 See Brussels Convention article 5 No 3; Case 21/76, Handelskwekerij GJ Bier v Mines de Potasse d'Alsace SA (1976) ECR 1735.

23 See FC von Savigny System des heutigen Römischen Rechts vol 8 (Veit und Comp., Leipzig 1849) 205-46.

24 See, eg, H Gaudemet-Tallon Les Conventions de Bruxelles et de Lugano (2ed Librairie générale de droit et de jurisprudence, Paris 1996) 133; Droz "Delendum est forum contractus" (1997) Recueil Dalloz Chronique 351; Kadner, "Gerichtsstand des Erfüllungsortes im GVÜ, Einheitliches Kaufrecht und internationalzivilprozessrechtliche Gerechtigkeit (1997) Jura 240. 
the EU. In marked contrast, an American Supreme Court decision specifically precludes such discrimination and, beyond that, requires courts to consider, in passing on the fairness of asserting jurisdiction, the burden imposed on nonresident individuals and enterprises who reside in distant countries and are unfamiliar with the forum's judicial system. ${ }^{25}$

But notwithstanding such deficiencies, the Brussels Convention and the Court of Justice's interperative endeavours nevertheless represent major progress in international procedural law and practice. Never in history have judgments circulated so freely among nations; never has international procedural law reached such heights of perfection. In three decades, European practice has attained a level of sophistication that is still lacking in the United States after more than two hundred years of experimentation. The Brussels Convention's provisions are, on the whole, far superior to the interstate jurisdictional and recognition practices that prevail in the US. Indeed, the Convention's merits are such that the progress they spell is no longer limited to the EU's member states: the remaining members of the European Free Trade Area have chosen to associate themselves with it the by entering into the Lugano Convention on Jurisdiction and the Recognition of Judgments in Civil and Commercial Matters. As for the rest of the world, the Brussels Conventions's regime can no doubt serve as a model for international procedural cooperation.

\section{F A Los Angeles Convention?}

In this connection it may be noted that the US is currently engaged - once again - in negotiating with other nations a multilateral treaty on judgments recognition under the auspices of the Hague Conference on Private International Law. Regrettably, the prospects of such a multilateral treaty do not look particularly promising. ${ }^{26}$ American state and federal courts recognise foreign country judgments fairly liberally, ${ }^{27}$ which reduces the incentives for other nations to bargain with the US. Also, the confusing and chaotic nature of American jurisdictional law poses obstacles to such an accord. Moreover, the fact that the Supreme Court has constitutionalised the subject of jurisdiction ties the American negotiators' hands. Finally, one may wonder about the wisdom of negotiating about judgments recognition with a multitude of nations that, unlike the member states of the EU, offer neither geographic

25 See Asahi Metal Ind Co v Superior Court 480 US 102 (1987).

26 See Juenger "A Hague Judgments Convention?" (1998) 24 Brooklyn J Int'l L 111.

27 For a comparative discussion of judgments recognition see Juenger "The Recognition of Money Judgments in Civil and Commercial Matters" (1988) 36 Am J Comp L 1. 
proximity nor common commercial policies (not to the mention considerable differences in their legal development).

If it were possible to write on a clean slate, a more expeditious way to assure the mutual recognition and enforcement of American and European judgments would be for the US to negotiate with the EU member states, as the former EFTA nations did, an international compact similar to the Lugano Convention, which might be dubbed the "Los Angeles Convention" (the name "New York Convention" having been preempted by the United Nations Convention on the Recognition and Enforcement of Foreign Arbitral Awards). Such negotiations would, at the same time, offer an opportunity to remedy the defects of American jurisdictional law. Even beyond the transatlantic area, the Brussels and Lugano Conventions invite comparison and may inspire emulation; indeed, as a member of the New Zealand Bar has suggested the "Lugano Convention, which takes an intelligent and coherent approach to these issues" might serve as a model for cross-Tasmanian judgments recognition and enforcement. ${ }^{28}$

\section{THE CHOICE OF LAW CONVENTION}

\section{A Choice of Law Doctrine}

\section{An academic province}

While international procedural law is far more important in practice, choice of law problems present a greater intellectual challenge. Much has been written about the subject since the glossators first discovered it, but to this day there is little agreement on even the most fundamental issues. In fact, one may wonder whether the rich academic literature that has accumulated over the centuries is of much help to judges and counsel dealing with actual cases. Joseph Story, who borrowed from civilian scholars because, in his words, they had "examined the subject with a much more comprehensive philosophy"29 than common lawyers, nevertheless criticised their "metaphysical subtleties, which perplex, if they do not confound, the inquirer". ${ }^{30}$ Nor have matters improved since. As Dean Prosser wrote: ${ }^{31}$

28 See Goddard, "The Changing Law of Contract - Problems in the Conflict of Laws" no 7 [unpublished paper delivered at the 1995 Journal of Contract Law Conference, on file with the author].

29 J Story Commentaries on the Conflict of Law (2ed A Maxwell, London, 1841) 12.

30 Above $n 29$.

31 Prosser "Interstate Publication" (1953) 51 Mich L Rev 959, 971. 
The realm of the conflict of laws is a dismal swamp, filled with quaking quagmires, and inhabited by learned but eccentric professors who theorize about mysterious matters in a strange and incomprehensible jargon. The ordinary court or lawyer is quite lost when engulfed and entangled in it.

2 The classical approach

As this quotation suggests, choice of law, invented as it was by academicians, has remained under the spell of dogma. Not only the civilian but also the common law rules in this field are largely based on doctrinal considerations espoused by the nineteenth century scholar Friedrich 
Carl von Savigny, ${ }^{32}$ who first articulated the multilateral approach to choice of law. Savigny divided the body of law into broad categories (such as contracts, property and family law), which he linked to a given legal system by means of connecting factors (such as the place of transaction, the situs of a thing or the domicile of a person). In this fashion he devised a set of "multilateral" precepts, ie rules that evenhandedly, without forum bias, invoke either foreign or domestic law. By allocating every conceivable legal relationship to the jurisdiction in which it has its closest connection, its "seat" or "home" as Savigny put it, ${ }^{33}$ he created a framework that commends itself by virtue of its elegance and apparent simplicity. Such a system could, in theory, resolve any choice of law problem that might present itself and yield identical results in multistate cases, irrespective of the forum in which a particular dispute is adjudicated.

\section{Lack of uniformity}

Of course, the classical multilateral rules can achieves the goal of "decisional harmony", as civilians call the avoidance of forum shopping, only if - as Savigny optimistically predicted- every state and nation of the world eventually adopts identical choice of law rules. ${ }^{34}$ It should come as no surprise that Savigny's rather unrealistic hope was disappointed. Not every jurisdiction classifies its legal rules and institutions in the same manner, nor does each one use identical connecting factors. The resulting divergencies engender what civilians call the "General Part", ie that portion of the conflict of laws which is devoted to such problems as renvoi, characterisation, the incidental question and public policy, self-inflicted conundrums that remind us that the quest for decisional harmony is quite quixotic. If further evidence were needed for that proposition, a wave of recent continental European codifications from Portugal to Russia, as well as legislation in the United Kingdom, shows that Savigny's dream of worldwide conformity has been laid to rest even on his native continent. While the new enactments still cling to his ideal, not two of them are alike; they merely further balkanise European of choice of law.

32 "[A]lthough it is true that the basis of the common law is not logic but experience, it is submitted that the method adopted in practice by English courts corresponds in general with that suggested by Savigny". PM North and JJ Fawcett Cheshire and North's Private International Law (12ed Butterworths, London Dublin Edinburgh 1992).

33 FC von Savigny above $\mathrm{n} 23$ at 108, 118, 120, 200.

34 Above $\mathrm{n} 33$ at 114 


\section{B The Convention}

\section{Reasons for the Convention}

There is, however, a way - of which Savigny was aware ${ }^{35}$ - to assure uniformity, namely the conclusion of choice of law treaties, which Savigny's successor Mancini advocated with great eloquence. Inspired by the success of the Brussels Convention, as well as the fear that its panoply of jurisdictional rules would promote forum shopping, the EU's member states again appointed a committee, which was to frame a choice of law convention as "natural sequel"36 to the earlier procedural compact. Among the reasons mentioned for this endeavour (for which the Rome Treaty offered no support) was, apart from the asserted need for predictability and the avoidance of forum shopping, the supposition that "the differences between national legal systems and the lack of unified rules of conflict definitely impede the free movement of persons, goods, services and capital among the Member States". ${ }^{37}$

After discussing the advisability of codifying, on a regional level, various areas of choice of law including contracts, torts, property and the "General Part", the committee prepared a draft that was limited to contractual and non-contractual obligations. Once the United Kingdom, Ireland and Denmark acceded to what was then the European Economic Community, the committee further narrowed its task to contract choice of law. Its work product, the Rome Convention on the Law Applicable to Contractual Relationships, has since been ratified by every EU member state. However, in contrast to the practice under the Brussels Convention, questions relating to its interpretation cannot be referred to the Court of Justice; a protocol akin to the Luxembourg Protocol has so far not been ratified by a sufficient number of states.

\section{Contract choice of law rules}

In contract choice of law hard and fast rules of the traditional type have not played much of a role. To be sure, the first Conflict of Laws Restatement ordained application of the lex loci contractus because its Reporter, Joseph Beale, believed that the "question whether a contract is valid ... can on general principle be determined by no other law than that which applies to

35 See above $\mathrm{n} 34$ at $114-15$.

36 M Giuliano and P Lagarde Report on the Convention on the Law Applicable to Contractual Obligations (1980) OJ (C 282) 1, 5.

37 Above n 36 at 4 (quoting T Vogelaar, then the Commission's Director-General for the Internal Market and Approximation of Legislation). 
the acts, that is, by the law of the place of contracting". ${ }^{38}$ In practical application, however, the lex loci contractus rule is highly unsatisfactory for a number of reasons. It causes problems whenever the parties to an agreement deal with each other across state lines by mail, telephone or some other means of communication, because it is often difficult to determine which act constitutes the offer and which the acceptance that completes the agreement. Even if the parties are present in the same state, the locus contractus may be entirely fortuitous, for instance, if they reach agreement in an airplane. Equally unsatisfactory is the lex loci solutionis. A contract usually imposes several obligations, not all of which are necessarily performed in the same state, so that several different laws would govern one and the same agreement.

\section{Party autonomy}

Instead of relying on choice of law rules of the traditional type courts, deferring to the substantive policy of freedom of contract, allow enterprises and individuals to stipulate the law they wish to govern their bargain. The principle of party autonomy is quite old; it probably predates Dumoulin, to whom it is customarily attributed. In the common law it prompted the famous dictum of Lord Mansfield that the governing law is that with a view to which the contract was made. ${ }^{39}$ This principle is of course incompatible with the classical system, which relies on value-free multilateral rules rather than substantive policy considerations. In fact, not only Beale but civilian scholars as well disparaged the idea that the parties, rather than multilateral conflicts rules of the traditional type, determine what law governs a contract. In Europe and elsewhere, however, courts, unperturbed by such scholarly scruples and cognizant of the fact that party autonomy guaranties "decisional harmony" far better than any hard and fast choice of law rule could, readily enforce choice of law clauses. Accordingly, it needed no convention to make this principle a fundamental tenet of contract choice of law in the EU.

Article 3 of the Rome Convention acknowledges this principle and clarifies a few details. Thus, according to article 3(1), second sentence, the choice of a particular law may be inferred from the terms of the contract; according to the third sentence, a dépeçage effect can be achieved by making a choice with respect to only part of the agreement; and article 3(2) permits a choice that changes the originally applicable law. More importantly, articles 5 and 6

38 J Beale A Treatise on the Conflict of Laws vol 2 (Baker Voorhis and Co, New York, 1935) 1091.

39 "[T]he general rule [that the lex loci contractus governs]. . . . admits of an exception when the parties ... had a view to a different kingdom". Robinson v Bland (1760) $1 \mathrm{Wm} \mathrm{Bl} \mathrm{234,258-59.}$ 
restrict party autonomy as regards consumer and employment contracts, and articles 3(3) and (7) restrict the parties' power to stipulate out of certain "mandatory rules". Implicitly, though not expressis verbis, the Convention imposes yet another important constraint on party autonomy: according to one of the Reporters, the Convention does not authorise the parties to choose a non-positive law (such as the lex mercatoria or the UNDROIT Principles of International Commercial Contracts) but only the law of some state or nation. ${ }^{40}$

4 Law applicable in the absence of choice

(a) Presumed intent

But what if a contract makes no provision for the applicable law? It may seem obvious that there is no room for party autonomy whenever the parties have failed to avail themselves of the power to designate the law they wish to govern. Dumoulin and Lord Mansfield, however, shared the opinion that the parties' choice need not be express; a mere implied or presumed intent should also be honoured, a proposition with which the US Supreme Court agreed at one time. ${ }^{41}$ Ever since d'Argentré derided this "mirificum Molinaei acumen", the notion of presumed intent has been recognised for what it is: a mere fiction. But, like others, this fiction has a benign effect. When thinking about what the contracting parties would have wished, had they only wished, judges can be expected to choose the law they believe ought to govern the particular agreement. Specifically, since the parties cannot reasonably be presumed to have intended to select a law that would invalidate their contract, the fiction of a pactum tacitum amounts, in effect, to a rule of validation.

(b) The "closest connection"

The drafters of the Rome Convention, however, rejected this subjective approach. Whilst article 3(1), as noted earlier, allows judges to infer a choice of the applicable law from the terms of an agreement, the Convention precludes them from to honouring a mere implied intent. The committee of experts, preferring objective criteria ${ }^{42}$ to the pseudo-psychological notion of a hypothetical intent, opted for a pseudo-geographical connecting factor: according to article $4(1)$, the law of the country with which the contract is "most closely connected" controls if the parties

40 Lagarde "Le nouveau droit international privé des contrats après l'entrée en vigeur de la Convention de Rome du 19 juin 1980" (1991) Revue critique de d.i.p. 287, 300-301.

41 Pritchard v Norton (1882) 106 US 124.

42 See Giuliano and Lagarde above n 36 at 19. 
fail to make a choice. This rather vague criterion ${ }^{43}$ is akin to the English "closest and most real connection" and the American "most significant relationship"44 mantras. Although it is less obviously teleological than the notion of "presumed intent", it still encourages judicial creativity because its indeterminacy confers a measure of discretion that allows judges to emphasise those contacts that lead to the law they wish to apply, eg that which validates the agreement.

\section{(c) The "characteristic performance"}

Judicial discretion, however, was something that the Rome Convention's framers did not cherish; they preferred more rigid connecting factors of the kind traditionally used in multilateral rules. While realising the problematic nature of such contacts as the place of contracting or performance, they tried nevertheless to give "specific form and objectivity to this, in itself, too vague concept of 'closest connection'". 45 To that end, they opted for a novel connecting factor. According to article 4(2), first sentence, it is presumed that a contract is most closely connected "with the country where the party who is to effect the performance which is characteristic of the contract has ... his habitual residence, or, in the case of a body corporate or unincorporate, its central administration". By choosing the performing party's home state rather than the place of performance, the drafters avoided application of a law whose connection with the agreement may be entirely fortuitous; by privileging one particular performance, they avoided the application of more than one law.

Whether the concept of "characteristic performance" has much to commend itself may well be doubted. In many cases - such as in contracts to publish a book or barter agreements - the concept does not work at all. Where it does work, that connecting factor confers an unwarranted choice of law privilege on those parties who professionally offer goods or services in the world market: according to article 4(2) these enterprises are entitled to have their home state law applied. As anyone who negotiates international contracts knows, application on one's own law is usually considered to be a definite advantage, for which a party must normally bargain and offer some quid pro quo. Finally, the added measure of

43 According to René David "The International Unification of Private Law" in International Encyclopedia of Comparative Law vol 2 (JCB Mohr (Paul Siebeck), Tübingen Mouton The Hague Paris, Oceana Publications Inc New York (1971) ch 5 at 8 "this formula means nothing except, perhaps, that the answer is not ready at hand".

44 See Restatement (Second) of Conflict of Laws s 188(1) (1971).

45 Giuliano and Lagarde above n 36 at 21. 
certainty the characteristic performance test is supposed to safeguard is undercut by article $4(5)$, according to which this criterion "shall be disregarded if it appears from the circumstances as a whole that the contract is more closely connected with another country". By referring to "the circumstances as a whole", article 4(5) reintroduces the very discretion that article 4(2) was supposed to curtail.

\section{A Model for Other Nations?}

Quite apart from its defects, one may well question whether the Rome Convention was really necessary. The fact that member states of the European Union may have different contract choice of law rules hardly impedes trade and commerce among them, as had been asserted in support of this project. ${ }^{46}$ In the US, for instance, where the approaches to contract choice of law range from interest analysis to the hoary place-of-contracting rule, ${ }^{47}$ these disparities have had no appreciable effect on the free movement of persons, goods, and services within that country. Also, whatever is good about the Rome Convention - such as party autonomy - it is not new, and whatever is new - such as the characteristic performance test - is not good. Because contracts are the lifeblood of international trade and commerce, the choice of law problems they engender require result-oriented pragmatism rather than faithful adherence to dogma. ${ }^{48}$ For this reason the framers of an inter-American contract choice of law convention negotiated under the auspices of the Organisation of American States specifically rejected several of the Rome Convention's salient features. ${ }^{49}$ Instead of relying exclusively on objective contacts, the Mexico City Convention left room for the finding of a "presumed intent"; it specifically authorised the choice of a non-positive law; and it deliberately omitted the "characteristic performance" test.

46 See above text accompanying $\mathrm{n} 37$.

47 For a recent listing of the contract choice of law approaches various American states follow see Symeonides "Choice of Law in the American Courts in 1996: Tenth Annual Survey" (1997) 45 Am J Comp L 447, 460.

48 The drafts produced by the committee of experts "as well as the accompanying legal discussion ... were, as far as argumentation and methods are concerned, rooted in classical private international law". Basedow, Der kollisionsrechtliche Gehalt der Produktfreiheiten im europäischen Binnenmarkt: favor referentis (1995) 59 Rabels Z 1, 3.

49 Concerning the Mexico City Convention see Juenger "The Inter-American Convention on the Law Applicable to International Contracts" (1994) 42 Am J Comp L 381. 


\section{CONCLUSION}

One of the two European conflicts conventions is exemplary, the other of questionable value. Whereas the drafters of the procedural compact took a pragmatic and result-oriented stance, those who wrote the Rome Convention failed to pay sufficient attention to substantive policy considerations and common sense solutions. Doctrinal considerations and "metaphysical subtleties" rather than the exigencies of international commerce prevailed; preoccupied with conflicts dogma and the ever-elusive quest for "decisional harmony", the drafters paid too little attention to practicalities. As a result, the Brussels/Lugano Conventions laid the foundation for a international law of civil procedure, whereas the Rome Convention does little to promote the emergence of a much needed European contracts law. Thus the Brussels/Lugano Conventions present a model for the world; the Rome Convention shows what other nations should avoid.

\section{DEUX CONVENTIONS EUROPÉENNES DE RÉSOLUTIONS DE CONFLITS DE LOI}

Les pays de l'Union Européenne ont conclu deux importantes conventions de résolutions de conflits de lois. La premiére dite Convention de Bruxelles de 1968 sur la compétence judiciaire et l'exécution des jugements, et la seconde dite Convention de Rome de 1980 sur la loi applicable aux obligations contractuelles. L'auteur évoque la genèse de ces conventions et à la lumiére de leur mise en oeuvre, précise quelle leur portée réelle. 